\title{
Article \\ Effects of Helicoverpa armigera Egg Age on Development, Reproduction, and Life Table Parameters of Trichogramma euproctidis
}

\author{
Nazanin Atashi ${ }^{1}\left(\mathbb{D}\right.$, Parviz Shishehbor ${ }^{1}$, Ali Asghar Seraj ${ }^{1}$, Arash Rasekh ${ }^{1}$, Seyed Ali Hemmati ${ }^{1}$ \\ and Eric W. Riddick ${ }^{2, *}$ \\ 1 Department of Plant Protection, Faculty of Agriculture, Shahid Chamran University of Ahvaz, \\ Ahvaz 61357-43311, Iran; Nazanin-Atashi@stu.scu.ac.ir (N.A.); pshishehbor@scu.ac.ir (P.S.); \\ seraj.a@scu.ac.ir (A.A.S.); a.rasekh@scu.ac.ir (A.R.); sa.hemmati@scu.ac.ir (S.A.H.) \\ 2 Agricultural Research Service, United States Department of Agriculture, Stoneville, MS 38776, USA \\ * Correspondence: eric.riddick@usda.gov
}

check for updates

Citation: Atashi, N.; Shishehbor, P.; Seraj, A.A.; Rasekh, A.; Hemmati, S.A.; Riddick, E.W. Effects of Helicoverpa armigera Egg Age on Development, Reproduction, and Life Table Parameters of Trichogramma euproctidis. Insects 2021, 12, 569. https://doi.org/10.3390/insects 12070569

Academic Editor: John J. Obrycki

Received: 29 April 2021

Accepted: 19 June 2021

Published: 22 June 2021

Publisher's Note: MDPI stays neutral with regard to jurisdictional claims in published maps and institutional affiliations.

Copyright: (c) 2021 by the authors. Licensee MDPI, Basel, Switzerland. This article is an open access article distributed under the terms and conditions of the Creative Commons Attribution (CC BY) license (https:// creativecommons.org/licenses/by/ $4.0 /)$.
Simple Summary: This study evaluated the potential of Trichogramma euproctidis to parasitize Helicoverpa armigera eggs of different ages in laboratory arenas. H. armigera is a major pest of agricultural crops in Iran and other countries. T. euproctidis is an important egg parasitoid of lepidopteran eggs and could be used in augmentative biological control of $H$. armigera. The objective of this research was to determine if young rather than old H. armigera eggs were optimal for T. euproctidis development, reproduction, and life table parameters. Results indicated that T. euproctidis developed faster and produced more offspring in $14 \mathrm{~h}$ old rather than $38 \mathrm{~h}$ or $62 \mathrm{~h}$ old $H$. armigera eggs. A life table analysis confirmed these results. This study is important because it documents for the first time that T. euproctidis can utilize H. armigera as a rearing host. Using young rather than old host eggs could ensure the persistence of a T. euproctidis mass production system to support augmentative releases.

Abstract: The noctuid Helicoverpa armigera is an economically important pest of agricultural crops in Iran and other countries. Research is evaluating the capacity of Trichogramma parasitoids to control $H$. armigera populations on field crops. The objective of this research was to determine if young rather than old $H$. armigera eggs were optimal for Trichogramma euproctidis development, reproduction, and life table parameters. Bioassays involved exposing T. euproctidis mated females to H. armigera 14, 38, or $62 \mathrm{~h}$ old eggs within $24 \mathrm{~h}$ in laboratory arenas. Results indicated that the number of host eggs parasitized successfully by T. euproctidis decreased as host egg age increased. Host egg age had no significant effect on T. euproctidis adult emergence. Adults that developed in $14 \mathrm{~h}$ old eggs had greater longevity and fecundity than those that developed in $38 \mathrm{~h}$ or $62 \mathrm{~h}$ old eggs. The intrinsic rate of increase $(r)$ was greatest, and the mean generation time (T) was lowest for T. euproctidis reared in $14 \mathrm{~h}$ old eggs. This study indicates that young H. armigera eggs are more suitable than old ones for T. euproctidis development and reproduction. This study is important because it provides evidence, for the first time, that T. euproctidis can utilize H. armigera as a rearing host. Using young rather than old host eggs could ensure the persistence of a T. euproctidis mass production system to support augmentative releases.

Keywords: biological control; endoparasitoid; life tables; natural enemy; reproduction

\section{Introduction}

Helicoverpa armigera (Hübner) (Lepidoptera: Noctuidae) is an important pest of agricultural crops around the world. If uncontrolled, it can significantly reduce production and yield of cotton (Gossypium hirsutum L.) in northeast Iran and tomato (Lycopersicon esculentum Mill.) in southwest Iran [1-5]. Synthetic chemical insecticides play an important role in the management of $H$. armigera. However, resistance of $H$. armigera to conventional 
insecticides has been reported in some countries such as Australia [5], China [6], India [7], Pakistan [8], Turkey [9], Iran [10], and France [11]. Using biological control as an alternative to conventional insecticides to manage $H$. armigera should be encouraged [12]. The development of techniques to conserve and utilize indigenous natural enemies, particularly predators and parasitoids that attack egg and larval stages, could be critical to successful biological control of $H$. armigera [12]. In addition, mass rearing and releasing the most important natural enemies could boost the chances of controlling H. armigera.

Trichogramma species (Hymenoptera: Trichogrammatidae) are commonly deployed to attack the egg stage of lepidopteran pests all over the world [13-16]. Trichogramma euproctidis (Girault), previously known as T. turkestanica Meyer [17], parasitized a noctuid Trichoplusia ni (Hübner), a plutellid Plutella xylostella (L.), and a pyralid Ephestia kuehniella Zeller in a laboratory study [18]. Large host eggs usually yielded larger-sized and more fecund T. euproctidis females [18]. Moreover, the size of hind tibia of T. euproctidis adult females was correlated to egg size (volume) of the hosts from which they emerged. Large T. euproctidis females emerged from $T$. ni eggs, which were the largest of the three host species; small adults emerged from P. xylostella eggs, which were the smallest of the host species. T. euproctidis progeny size (egg volume) was greatest for females that emerged from T. ni eggs [18]. In field studies, T. euproctidis parasitized the gelechiid Tuta absoluta (Meyrick), a major pest of tomato in greenhouses in Egypt $[19,20]$.

Many factors such as host egg age affect the success of an egg parasitoid [21,22]. Young host eggs are usually preferred over old eggs. For example, Trichogramma cacoeciae Marchal parasitized more 1-2 d old than 3-4 d old hosts, Lobesia botrana Denis and Schiffermüller (Lepidoptera: Tortricidae), in the laboratory [15]. Note that young rather than old (black head) eggs of Diatraea grandiosella Dyar (Lepidoptera: Crambidae) were preferred as a host by Trichogramma pretiosum Riley [23]. In the cases where old D. grandiosella eggs were parasitized, egg yolk was still present and T. pretiosum eggs were always located within it [23]. Trichogramma larvae are semi-liquid feeders that use extra-oral and intra-oral digestion to consume host egg yolk and other egg materials [24,25]. Host eggs become less suitable as they get older, possibly because they contain less yolk or because they have a thicker cuticle (chorion), which could limit envenomation of host eggs by Trichogramma females [26]. These laboratory studies suggest that Trichogramma mass rearing efforts would be more successful when young, rather than old, host eggs were provided as hosts.

Although several Trichogramma species are known to parasitize H. armigera eggs in the field $[27,28]$ or laboratory [29-31], T. euproctidis is not one of them. Therefore, the aim of this study is to provide baseline information on parasitism of $H$. armigera and its suitability as a host for T. euproctidis in the laboratory. The specific objective of this research is to determine if young rather than old $H$. armigera eggs are optimal for T. euproctidis development, reproduction, and life table parameters. This research should provide clues to developing efficient mass rearing systems for T. euproctidis.

\section{Materials and Methods}

\subsection{Insect Collection}

A colony of T. euproctidis was originally obtained by pasting E. kuehniella egg masses on white paper ( $5 \mathrm{~cm}$ length, $1 \mathrm{~cm}$ width) then attaching to foliage in a corn field on the premises of Shahid Chamran University of Ahvaz ( $31^{\circ} 17^{\prime} 59^{\prime \prime}$ N, $48^{\circ} 39^{\prime} 39^{\prime \prime}$ E), Ahvaz, Iran, during July 2019. The species was identified using SEM micrographs of male genital capsules [32]. Voucher specimens were deposited in the collection of Department of Plant Protection, Shahid Chamran University of Ahvaz, Ahvaz, Iran, and the Natural History Museum, London, UK. The colony of T. euproctidis was maintained using the eggs of E. kuehniella under conditions of $25 \pm 1{ }^{\circ} \mathrm{C}, 55 \pm 5 \% \mathrm{RH}$, with a 16:8 L/D regime. For mass rearing of Trichogramma species, E. kuehniella eggs are often used as hosts [13] because they only support the complete development of one parasitoid, rarely two, after emergence [13]. The E. kuehniella eggs used in this study were obtained from a colony 
maintained at Golestan Mooud Insectary Company, Ahvaz, Iran. T. euproctidis was reared from E. kuehniella eggs for five to six generations in the laboratory prior to experimentation.

Helicoverpa armigera eggs were obtained from a laboratory culture reared on a beanyeast based semi-artificial diet [33] at the University of Guilan, Rasht, Iran, and reared continuously on the same diet at $25 \pm 1{ }^{\circ} \mathrm{C}, 55 \pm 5 \% \mathrm{RH}$, and a photoperiod of 16:8 (L/D). After emergence, $H$. armigera females were confined with potted geranium, Pelargonium zonale (L.), 2-month-old seedlings in a cage (diameter $50 \mathrm{~cm}$, height $40 \mathrm{~cm}$ ) for oviposition. Eggs laid on geranium leaves within a 40-min period were maintained at $25 \pm 1{ }^{\circ} \mathrm{C}$ until they were either 14,38 , or $62 \mathrm{~h}$ old. The midpoint of the 40 -min period was used as the starting point for determining egg age.

\subsection{Experimental Procedure}

A preliminary experiment showed that at $25^{\circ} \mathrm{C}, \mathrm{H}$. armigera eggs take less than $4 \mathrm{~d}$ to hatch (N.A. and P.S., unpublished data). Consequently, 14 h, 38 h, and 62 h old H. armigera eggs were selected as test hosts. The newly emerged T. euproctidis adult females were confined with males for $8 \mathrm{~h}$, then introduced into a clear glass tube (diameter $1 \mathrm{~cm}$, height $10 \mathrm{~cm}$ ) containing a $H$. armigera egg mass. The glass tubes were sealed with cotton wool. Each egg mass of $H$. armigera used in our experiments contained 40 eggs. Egg masses were glued on a piece of white paper $(5 \mathrm{~cm}$ length, $1 \mathrm{~cm}$ width). Parasitoids had not been in contact with host eggs before the tests. Female parasitoids were fed with droplets of honey deposited in the inner wall of each tube during the experiments. The female parasitoid was allowed to parasitize $H$. armigera eggs in a growth chamber $\left(25 \pm 1{ }^{\circ} \mathrm{C}\right.$, $55 \pm 5 \% \mathrm{RH}, 16: 8 \mathrm{~L} / \mathrm{D})$ for $24 \mathrm{~h}$. The parasitoid was removed after $24 \mathrm{~h}$ and tubes were kept in the incubator until all parasitoid progeny emerged. Ten replications were used for each egg age. The experiment was carried out in a completely randomized design. The number of parasitized $H$. armigera eggs from each glass tube was determined under a stereo zoom microscope six days after the parasitoid was removed. The date of emergence of T. euproctidis adults was recorded to estimate the duration of pre-imaginal development. In addition, survival rate (percentage of adult emergence), number of parasitoids emerged per egg, the sex of emerging wasps, and the size of right hind tibia (as an estimate of body size $[34,35])$ of female and male parasitoids were recorded using a stereo zoom microscope.

The effect of host egg age on longevity and fecundity of adult progeny was studied by placing one adult female and one adult male (less than $24 \mathrm{~h}$ old) in a glass tube (as in tubes described in the previous experiment) containing an egg mass of 40, $1 \mathrm{~d}$ old $\mathrm{H}$. armigera, and honey. Males were replaced in case they died early in the experiment. New eggs were offered daily to each female until all females were dead. The experiment was carried out in a completely randomized design. This experiment was also conducted in a growth chamber $\left(25 \pm 1{ }^{\circ} \mathrm{C}, 55 \pm 5 \%\right.$ R.H. and 16:8 L/D). Longevity and fecundity of parasitoids were calculated. Those females which were injured during daily handling or those that died because of getting stuck in honey droplets were excluded from data analysis.

\subsection{Statistical Analysis}

All data on number of host eggs parasitized, percentage survival rate, developmental time of offspring, percentage of female progeny, number of parasitoids per host egg, size of hind tibia, and longevity and fecundity of progeny were tested for normality using the Kolmogorov-Smirnov test. The data were analyzed using one-way analysis of variance (ANOVA). Percentage survival rate and percentage of female progeny were arcsine transformed to homogenize variances prior to the one-way ANOVA. Mean values were separated using Tukey's honest significant difference (HSD) test at $\alpha=0.05$. SPSS version 22 statistical software was used to analyze the data [36].

Life table parameters were estimated by combining data from the pre-imaginal development, adult survival, and reproduction experiment of different host egg age treatments. The intrinsic rates of population increase were estimated by iteratively solving the following equation: $\Sigma \mathrm{e}^{r \mathrm{x} l \mathrm{l} m \mathrm{x}}=1$ [37], where $\mathrm{x}$ is the mean age class, $m_{\mathrm{x}}$ is the mean number 
of female progeny per female of age $x$, and $l_{x}$ is the probability of survival to age $x$. A trial number of values for $r$ were substituted into the equation until the $r$ value for which the sum on the left side of the equation approximates unity. The Jacknife procedure was used to estimate an SE for the $r$ values of different treatments [38]. Further data were also calculated for each treatment: net reproductive rate $\left(R_{0}=\Sigma l_{\mathrm{x}} m_{\mathrm{x}}\right.$, number of female offspring produced per female), mean generation time $\left(\mathrm{T}=\mathrm{Ln} R_{0} / r\right)$, doubling time (DT $=\ln$ $2 / r$, number of days required for the population to double in numbers), and finite rate of increase $\left(\lambda=\mathrm{e}^{r}\right.$, number of times the population will multiply itself per unit of time) [37]. Standard error of the population growth parameters was achieved by using the bootstrap technique, and multiple comparisons were made possible using the paired bootstrap test with 100,000 samples.

\section{Results}

Host age had a significant effect on the mean number of eggs parasitized by T. euproctidis $(\mathrm{F}=32.43 ; \mathrm{df}=2,27 ; p<0.0001)$ (Table 1$)$. The number of parasitized eggs decreased as egg age increased. Mean number of $14 \mathrm{~h}$ old eggs parasitized by T. euproctidis was two times higher than for $38 \mathrm{~h}$ and $62 \mathrm{~h}$ old eggs. Preimaginal developmental times for T. euproctidis were significantly affected by host age (females: $\mathrm{F}=190.82 ; \mathrm{df}=2,393$; $p<0.0001$; males: $\mathrm{F}=35.38 ; \mathrm{df}=2$, 233; $p<0.0001$ ) (Table 1). Developmental time of T. euproctidis females and males were shortest on $14 \mathrm{~h}$ old host eggs. There was no significant difference in development time of males and females between $38 \mathrm{~h}$ and $62 \mathrm{~h}$ old host eggs. The host egg age had no significant effect on survival rate (adult emergence) $(\mathrm{F}=2.46$; $\mathrm{df}=2,27$; $p=0.104)$ (Table 1).

Table 1. Parasitism and biological parameters of T. euproctidis emerging from H. armigera eggs of different ages. Data represent mean $( \pm \mathrm{SE})$ values.

\begin{tabular}{cccc}
\hline Parameter & \multicolumn{3}{c}{ H. armigera Egg Age (h) } \\
\cline { 2 - 4 } & $\mathbf{1 4}$ & $\mathbf{3 8}$ & $\mathbf{6 2}$ \\
\hline Number of parasitized eggs & $30.80 \pm 2.18^{\mathrm{a}}$ & $15.0 \pm 1.77^{\mathrm{b}}$ & $11.60 \pm 1.34^{\mathrm{b}}$ \\
Female development time (d) & $10.07 \pm 0.05^{\mathrm{c}}$ & $11.57 \pm 0.08^{\mathrm{b}}$ & $12.07 \pm 0.10^{\mathrm{b}}$ \\
Male development time (d) & $10.28 \pm 0.07^{\mathrm{b}}$ & $11.26 \pm 0.12^{\mathrm{a}}$ & $11.41 \pm 0.19^{\mathrm{a}}$ \\
Survival rate (\%) & $94.10 \pm 1.38^{\mathrm{a}}$ & $93.4 \pm 1.79^{\mathrm{a}}$ & $88.50 \pm 2.49^{\mathrm{a}}$ \\
Sex ratio (\% female) & $73.70 \pm 3.99^{\mathrm{a}}$ & $64.70 \pm 3.45^{\mathrm{b}}$ & $59.80 \pm 3.72^{\mathrm{c}}$ \\
Size (mm) of right hind tibia (female) & $0.180 \pm 0.056^{\mathrm{a}}$ & $0.172 \pm 0.085^{\mathrm{b}}$ & $0.160 \pm 0.080^{\mathrm{c}}$ \\
Size (mm) of right hind tibia (male) & $0.170 \pm 0.073^{\mathrm{a}}$ & $0.160 \pm 0.092^{\mathrm{b}}$ & $0.150 \pm 0.030^{\mathrm{c}}$ \\
Number of parasitoids/host egg & $1.2 \pm 0.45^{\mathrm{a}}$ & $1.1 \pm 0.36^{\mathrm{ab}}$ & $1.03 \pm 0.43^{\mathrm{b}}$ \\
\hline
\end{tabular}

abc Mean values in a row followed by the same letters are not significantly different at $p>0.05$ (Tukey's HSD test).

Sex ratio (proportion of female progeny) was significantly affected by host egg age $(\mathrm{F}=4.81 ; \mathrm{df}=2,27 ; p=0.016)$ (Table 1$)$. A female biased sex ratio was observed on all egg ages tested, but percentage of female progeny declined as $H$. armigera egg age increased. The host egg age had a significant effect on size of right tibial length of emerging parasitoids (females: $\mathrm{F}=204.61 ; \mathrm{df}=2,212 ; p<0.0001$; males: $\mathrm{F}=57.82 ; \mathrm{df}=2,141 ; p<0.0001$; Table 1). Size of right tibial length of parasitoids steadily decreased as host egg age increased. The number of parasitoids emerging from each host egg was significantly affected by the age of the host $(\mathrm{F}=3.51 ; \mathrm{df}=2,27 ; p=0.04)$ (Table 1$)$.

Host age had a significant effect on female longevity $(\mathrm{F}=148.87 ; \mathrm{df}=2,87 ; p<0.001)$ (Table 2). The longest-lived T. euproctidis females emerged from $14 \mathrm{~h}$ old eggs (6.92 d). The mean daily and total number of eggs oviposited by T. euproctidis females emerging from different host ages were significantly different (daily fecundity: $\mathrm{F}=53.79 ; \mathrm{df}=2,87$; $p<0.001$; total fecundity: $\mathrm{F}=67.53 ; \mathrm{df}=2,87 ; p<0.001$ ) (Table 2). Female T. euproctidis oviposited a mean number of 67.73 eggs on $14 \mathrm{~h}$ old $H$. armigera eggs compared to 19.50 eggs on $62 \mathrm{~h}$ old host eggs. 
Life table parameter statistics emphasized that $14 \mathrm{~h}$ old eggs were a preferable host egg age for T. euproctidis compared with other host ages tested (Table 3). As a result of accelerated development duration and greater fecundity early in adulthood, T. euproctidis reared on $14 \mathrm{~h}$ old eggs had a significantly greater gross reproduction rate (GRR), net reproduction rate $\left(\mathrm{R}_{0}\right)$, and intrinsic rate of natural increase $(r)$ than those bred on other host egg ages tested (Table 3 ). In addition, the shortest and longest mean generation times of T. euproctidis were obtained on the $14 \mathrm{~h}$ old eggs and $62 \mathrm{~h}$ old eggs, respectively. Age-specific survival $\left(l_{\mathrm{x}}\right)$ and fecundity $\left(m_{\mathrm{x}}\right)$ curves derived from these data for each tested host egg age are illustrated in Figure 1.
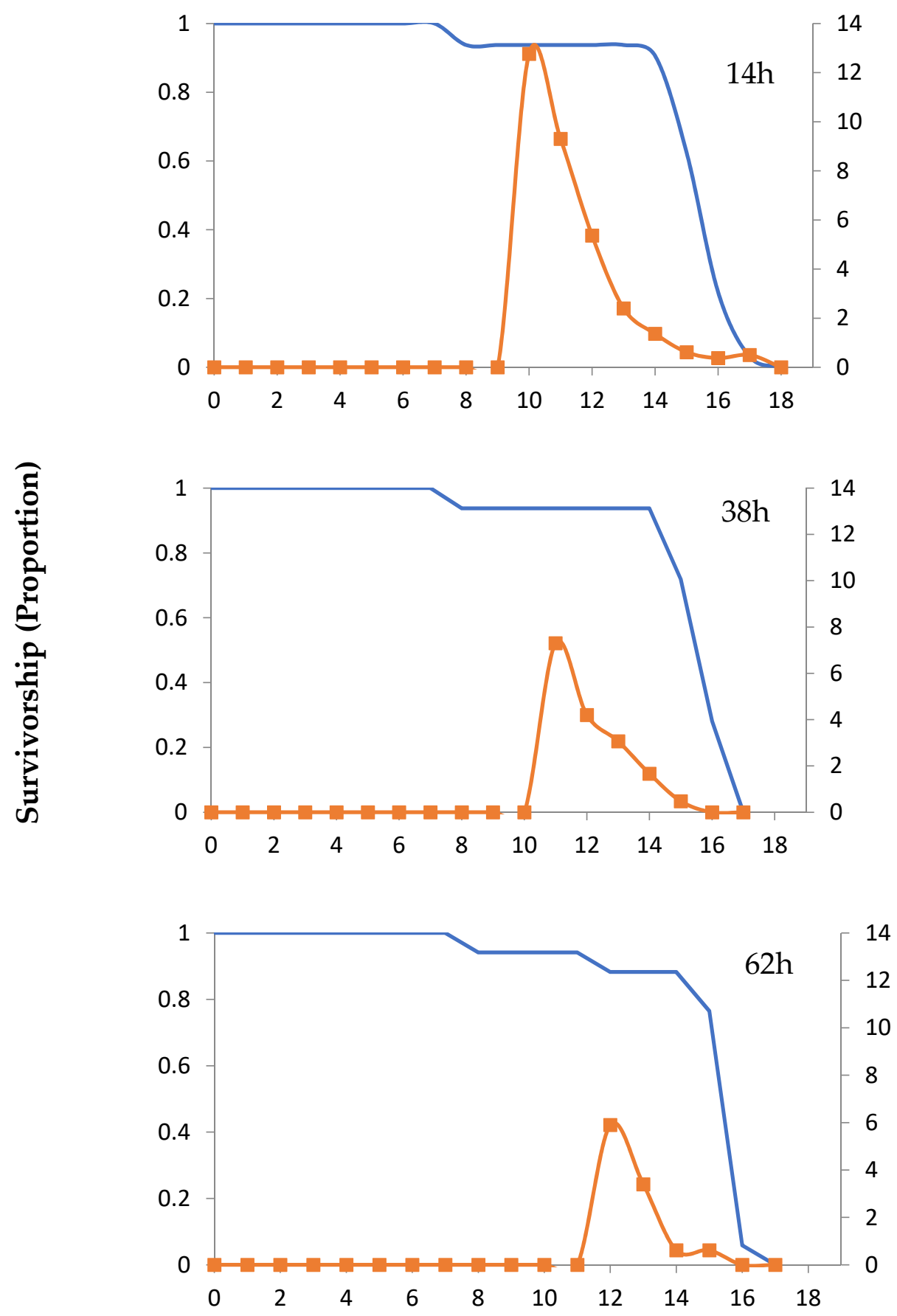

\section{Days after emergence}

Figure 1. Proportional survivorship ( $l_{x}$, solid blue lines) and number of T. euproctidis female progeny per female per day ( $m_{\mathrm{x}}$, dotted orange lines) from $H$. armigera eggs of different ages. 
Table 2. Mean ( \pm SE) oviposition period, female and male longevity $(\mathrm{d})$, and diel and total fecundity of T. euproctidis reared from $H$. armigera eggs of different ages.

\begin{tabular}{cccc}
\hline \multirow{2}{*}{ Parameters } & \multicolumn{3}{c}{ H. armigera Egg Age (h) } \\
\cline { 2 - 4 } & $\mathbf{1 4}$ & $\mathbf{3 8}$ & $\mathbf{6 2}$ \\
\hline Oviposition period (d) & $5.19 \pm 0.237^{\mathrm{a}}$ & $4.46 \pm 0.124^{\mathrm{b}}$ & $3.62 \pm 0.090^{\mathrm{c}}$ \\
Female longevity (d) & $6.92 \pm 0.159^{\mathrm{a}}$ & $5.017 \pm 0.122^{\mathrm{b}}$ & $3.99 \pm 0.70^{\mathrm{c}}$ \\
Male longevity (d) & $4.59 \pm 0.183^{\mathrm{a}}$ & $2.86 \pm 0.124^{\mathrm{b}}$ & $1.829 \pm 0.128^{\mathrm{c}}$ \\
Diel fecundity & $10.83 \pm 0.657^{\mathrm{a}}$ & $6.84 \pm 0.67^{\mathrm{b}}$ & $5.32 \pm 0.36^{\mathrm{b}}$ \\
Total fecundity & $67.73 \pm 4.33^{\mathrm{a}}$ & $31.90 \pm 3.73^{\mathrm{b}}$ & $19.5 \pm 2.91^{\mathrm{c}}$ \\
\hline
\end{tabular}

abc Mean values in a row followed by the same letters are not significantly different at $p>0.05$ (Tukey's HSD test)

Table 3. Mean $( \pm \mathrm{SE})$ values of life table parameters for T. euproctidis reared from H. armigera eggs of different ages.

\begin{tabular}{cccc}
\hline \multirow{2}{*}{ Parameters } & \multicolumn{3}{c}{ H. armigera Egg Age (h) } \\
\cline { 2 - 4 } & $\mathbf{1 4}$ & $\mathbf{3 8}$ & $\mathbf{6 2}$ \\
\hline GRR (offspring/Generation) & $32.6904 \pm 0.1041^{\mathrm{a}}$ & $16.7116 \pm 0.0482^{\mathrm{b}}$ & $10.5308 \pm 0.274^{\mathrm{c}}$ \\
$\mathrm{R}_{0}$ (offspring/Generation) & $30.1514 \pm 0.091^{\mathrm{a}}$ & $14.8696 \pm 0.041^{\mathrm{b}}$ & $9.2195 \pm 0.023^{\mathrm{c}}$ \\
$r\left(\mathrm{~d}^{-1}\right)$ & $0.3112 \pm 0.00026^{\mathrm{a}}$ & $0.2288 \pm 0.00023^{\mathrm{b}}$ & $0.1771 \pm 0.0002^{\mathrm{c}}$ \\
$\lambda\left(\mathrm{d}^{-1}\right)$ & $1.3651 \pm 0.0003^{\mathrm{a}}$ & $1.2571 \pm 0.0029^{\mathrm{b}}$ & $1.1938 \pm 0.0002^{\mathrm{c}}$ \\
$\mathrm{T}(\mathrm{d})$ & $10.9437 \pm 0.0016^{\mathrm{c}}$ & $11.7974 \pm 0.0028^{\mathrm{b}}$ & $12.5409 \pm 0.0012^{\mathrm{a}}$ \\
$\mathrm{DT}(\mathrm{d})$ & $2.2271 \pm 0.0018^{\mathrm{c}}$ & $3.0296 \pm 0.0031^{\mathrm{b}}$ & $3.9136 \pm 0.0044^{\mathrm{a}}$ \\
\hline
\end{tabular}

abc Values in rows followed by the same small letter are not significantly different using the paired bootstrap test at $5 \%$ significance level. Note that $r$ is the intrinsic rate of increase, $\lambda$ is finite rate of increase, T is mean generation time in days, and DT is doubling time in days.

\section{Discussion}

In this study, all H. armigera eggs were accepted by T. euproctidis females as suitable hosts. However, $14 \mathrm{~h}$ old eggs were parasitized at a twofold higher rate than the other egg ages, suggesting a preference for younger eggs. T. euproctidis was able to develop faster in young rather than old host eggs. Trichogramma species often develop and survive better on young host eggs [39], perhaps because essential nutrients in the host egg are progressively incorporated into and assimilated by the host embryo, becoming less available to support parasitoid development [40]. Moreover, Trichogramma species are occasionally unable to complete development inside old host eggs [41], possibly due to the rotation of the host embryo or sclerotization of its head capsule [23]. Lepidopteran eggs that have completed $75 \%$ or more of their embryonic development are not suitable for Trichogramma development [23].

The age of the H. armigera host egg did not affect survival rate (emergence rate) of T. euproctidis offspring. Similar results were also reported for Trichogramma chilonis Ishii emerging from Plutella xylostella (L.) [42], Trichogramma cacoeciae Marchal, Trichogramma principium Sugonjaev \& Sorokina, and Trichogramma evanescens Westwood from Phythorimaea operculella (Zeller) [43], T. cacoeciae from Lobesia botrana Denis and Schiffermuller [15], T. pretiosum from Mocis latipes (Guenee) [44], and Trichogramma galloi Zucchi from Diatraea saccharalis (F.) [45]. However, T. evanescens offspring survival rate declined as E. kuehniella egg age increased. On the basis of these studies, we found that lack of host age effects on parasitoid survival is the norm rather than the exception in Trichogramma species.

Variable results have been reported on the impact of host egg age on sex ratio of progeny of Trichogramma species [23]. The age of H. armigera eggs had a significant effect on T. euproctidis progeny sex ratio, and it should be noted that the sex ratio was biased toward females for all host egg ages tested. Sex ratio (percentage of female progeny) declined when T. euproctidis parasitized older E. kuehniella eggs [22]. Moreover, E. kuehniella and Sitotroga cerealella Olivier egg ages had a significant effect on sex ratio of T. evanescens; younger eggs produced more female parasitoids [46]. However, host egg age did not affect the sex ratio 
of T. pretiosum (Riley) reared from D. grandiosella [31], T. principium from S. cerealella [47], T. brassicae from Trichoplusia ni (Hübner) and Pieris rapae (L.) [39], Trichogramma dendrolimi Matsumura from Mamestra brassicae (L.) [48], T. cacoeciae from L. botrana [49], Trichogramma fuentesi Torre from Cactoblastis cactorum (Berg) [50], and T. dendrolimi from Chilo suppressalis (Walker) [51]. These differences may be explained by differences in Trichogramma species, host species, or experimental conditions.

Parasitoid body size was affected by the age of host eggs. Female T. euproctidis right tibia were longer upon emergence from young rather than old $H$. armigera eggs. Similarly, T. pretiosum tibial length was greatest on individuals emerging from young rather than old H. zea eggs [40]. Tibial length is commonly used as a measure of body size; longer tibia positively correlates with larger body size of parasitoids [34,35]. Body size has a direct relationship with female longevity and/or fecundity of egg parasitoids; larger females typically live longer and produce more progeny $[52,53]$. Therefore, the age of the host eggs in which T. euproctidis develop may have an immediate effect on developmental time and a long-term effect on female fitness.

Host egg age had a significant effect on the number of parasitoids that developed per egg, and the number of offspring that emerged per egg was continuously more than one progeny per parasitized egg. This was attributed to the size of $H$. armigera eggs, which were from 0.42 to $0.60 \mathrm{~mm}$ [54] compared to the eggs of the factitious host E. kuehniella, which were approximately $0.3 \mathrm{~mm}$ [55]. These findings suggest that availability of a larger amount of nutrients (i.e., yolk) in the host egg could support the development of more than one parasitoid. However, when more than one parasitoid develops in the same host egg, there may be competition for nutrients resulting in smaller offspring, which in turn result in lower longevity and fecundity of emerged parasitoids [56].

At $25{ }^{\circ} \mathrm{C}$, mean longevities of T. euproctidis females parasitizing $1 \mathrm{~d}$ old E. kuehniella eggs were $8.9 \mathrm{~d}$ [57] and $9.8 \mathrm{~d}$ [22] compared to $6.9 \mathrm{~d}$ for females parasitizing $1 \mathrm{~d}$ old $H$. armigera eggs in this study. Mean total fecundities of T. euproctidis parasitizing $1 \mathrm{~d}$ old E. kuehniella eggs were 82.1 eggs [57] and 78.9 eggs [22] at $25^{\circ} \mathrm{C}$ in comparison to 67.7 eggs for females parasitizing H. armigera eggs in this study. Differences in host species and experimental conditions (e.g., humidity) could account for the lower fecundity of T. euproctidis. The rearing history of T. euproctidis could have affected fecundity. The T. euproctidis colony was maintained on E. kuehniella eggs for several generations prior to beginning this experiment. Laboratory adaptation to the rearing host could partly explain why T. euproctidis females were more fecund when reared from E. kuehniella eggs (in previous studies) rather than H. armigera eggs, in this study. Future research could include both host species, i.e., factitious versus new host, in the same experimental design to test the influence of laboratory adaptation on T. euproctidis fecundity.

Host egg age affected the biological performance of T. euproctidis, as demonstrated in its intrinsic rate of increase $(r)$. Intrinsic rate of increase reflects survival and reproduction of the parasitoid [58]. The highest $r$ value $(0.311 / \mathrm{d})$ was recorded for progeny produced in $14 \mathrm{~h}$ old host eggs. At the same temperature, T. euproctidis had a $r$ value of $0.354 / \mathrm{d}$ from the same egg age, i.e., $24 \mathrm{~h}$ old E. kuehniella eggs [22]. The discrepancy between the results of the mentioned study and this study may be due to differences in the size of host species.

In conclusion, T. euproctidis developed faster in $14 \mathrm{~h}$ old H. armigera eggs and produced significantly more offspring than other egg ages tested. Although T. euproctidis developed and emerged successfully from all $\mathrm{H}$. armigera egg ages, the outcome was decreased female progeny, decreased body size of progeny, and decreased population growth rate when older H. armigera eggs were utilized as hosts. The long-term fitness of a T. euproctidis colony would decline. Therefore, this study suggests that young-aged $H$. armigera eggs be used in a system designed to mass produce T. euproctidis for augmentative releases. Moreover, this study could suggest that T. euproctidis adults should be released as soon as H. armigera adults are first detected in crop fields. This would increase the likelihood that T. euproctidis females locate and parasitize young rather than old H. armigera eggs. This strategy could improve the persistence of T. euproctidis in the field during the growing season. 
Author Contributions: Conceptualization, P.S., A.A.S. and A.R.; methodology, P.S., A.R., and S.A.H.; software, N.A. and AR.; validation, N.A., P.S., and S.A.H.; formal analysis, N.A.; investigation, N.A., P.S., A.R., and S.A.H.; resources, P.S.; data curation, N.A.; writing-original draft preparation, P.S. and E.W.R.; writing-review and editing, E.W.R.; visualization, N.A.; supervision, P.S.; project administration, P.S.; funding acquisition, P.S. All authors have read and agreed to the published version of the manuscript.

Funding: This research was financially supported by Shahid Chamran University of Ahvaz, (grant no. SCU.AP98.400).

Institutional Review Board Statement: Not applicable.

Informed Consent Statement: Not applicable.

Data Availability Statement: The authors can provide supporting data on ResearchGate.

Acknowledgments: The Research Deputy of Shahid Chamran University of Ahvaz is acknowledged for supporting this research. The comments of three anonymous peer reviewers improved the text. The U.S. government has the right to retain a non-exclusive, royalty-free license in and to any copyright of this article. This article reports the results of research only. Mention of a commercial or proprietary product does not constitute an endorsement of the product by the U.S. Department of Agriculture.

Conflicts of Interest: The authors declare no conflict of interest.

\section{References}

1. Behdad, B. Pests of Field Crops in Iran; Isfahan Neshat Press: Isfahan, Iran, 1982.

2. Metcalf, R.A.; Metcalf, M.D. Destructive and Useful Insects: Their Habits and Control, 5th ed.; McGraw-Hill Inc.: New York, NY, USA, 1993.

3. Mossadegh, M.S.; Kocheili, F. A Semi-Descriptive Checklist of Identified Species of Arthropods (Agricultural, Medical, ... ) and Other Pests from Khuzestan, Iran; Shahid Chamran University Press: Ahvaz, Iran, 2003.

4. Khanjani, M. Field Crop Pests in Iran. (Insects and Mites); Bu-Ali Sina University Press: Hamedan, Iran, 2005.

5. Fitt, G.P. Cotton pest management. Part 3. An Australian perspective. Annu. Rev. Entomol. 1994, 39, 543-562. [CrossRef]

6. Xia, J.Y. Status and management of insecticide resistance of cotton insect pests in China (Mainland). ICAC Rec. 1993, 9, 10-14.

7. Armes, N.J.; Jadhav, D.R.; DeSouza, K.R. A survey of insecticide resistance in Helicoverpa armigera in the Indian subcontinent. Bull. Entomol. Res. 1996, 86, 499-514. [CrossRef]

8. Ahmad, M.; Arif, M.I.; Ahmad, Z. Patterns of resistance to organophosphate insecticides in field populations of Helicoverpa armigera in Pakistan. Pestic. Sci. 1999, 55, 626-632. [CrossRef]

9. Ernst, G.; Dittrich, V. Comparative measurements of resistance to insecticides in three closely related old and new world bollworm species. Pestic. Sci. 1992, 34, 147-152. [CrossRef]

10. Mossallanezhad, H.; Norouzi, M.; Mohammadbeigi, A. List of Important Plant Pests, Disease, Weeds and Recommended Pesticides; Educational Agricultural Publisher: Tehran, Iran, 2003. (In Persian)

11. Buès, R.; Bouvier, J.C.; Boudinhon, L. Insecticide resistance and mechanisms of resistance to selected strains of Helicoverpa armigera (Lepidoptera: Noctuidae) in the south of France. Crop. Prot. 2005, 24, 814-820. [CrossRef]

12. Cherry, A.; Cock, M.; van den Berg, H.; Kfir, R. Biological control of Helicoverpa armigera in Africa. In Biological Control in IPM Systems in Africa; Neuenschwander, P., Borgemeister, C., Langewald, J., Eds.; CAB International: Wallingford, UK, 2003; pp. 329-346.

13. Smith, S.M. Biological control with Trichogramma: Advances, successes, and potential for their use. Annu. Rev. Entomol. 1996, 41, 375-406. [CrossRef]

14. Tabone, T.; Bardon, C.; Desneux, N.; Wajnberg, E. Comparative assessment of parasitism of different Trichogramma species and strains on Plutella xylostella L. on greenhouse cauliflower. J. Pest. Sci. 2010, 83, 251-256. [CrossRef]

15. Pizzol, J.; Desneux, N.; Wajnberg, E.; Thiery, D. Parasitoid and host egg ages have independent impact on various biological traits in a Trichogramma species. J. Pest. Sci. 2012, 85, 489-496. [CrossRef]

16. Chailleux, A.; Desneux, N.; Seguret, J.; Khanh, H.D.T.; Maignet, P.; Tabone, E. Assessing European egg parasitoids as a mean of controlling the invasive South American tomato pinworm Tuta absoluta. PLoS ONE 2012, 7, e48068. [CrossRef] [PubMed]

17. Rohi, L.; Pintureau, B. Reassessment of Trichogramma euproctidis (Girault, 1911) (Hymenoptera: Trichogrammatidae). Russian Entomol. J. 2003, 12, 373-379.

18. Martel, V.; Darrouzet, E.; Boivin, G. Phenotypic plasticity in the reproductive traits of a parasitoid. J. Insect Physiol. 2011, 57, 682-687. [CrossRef]

19. El-Arnaouty, S.A.; Pizzol, J.; Galal, H.H.; Kortam, M.N.; Afifi, A.I.; Beyssat, V.; Desneux, N.; Biondi, A.; Heika, I.H. Assessment of two Trichogramma species for the control of Tuta absoluta in North African tomato greenhouses. Afr. Entomol. 2014, 22, 801-809. [CrossRef] 
20. Adly, D.; Nouh, G.M. Impact of combine releases of the egg parasitoid, Trichogramma euproctidis (Girault) and the entomopathogenic nematode, Heterorhabditis bacteriophora to control Tuta absoluta (Meyrick) in tomato greenhouses in Egypt. Egypt. J. Pest. Control. 2019, 29, 91. [CrossRef]

21. Pak, G.A. Behavioral variations among strains of Trichogramma spp.: A review of the literature on host-age selection. J. Appl. Entomol. 1986, 101, 55-64. [CrossRef]

22. Tabebordbar, F.; Shishehbor, P.; Ebrahimi, E. Suitability of different egg ages of Ephestia kuehniella (Lep.: Pyralidae) for the development, reproduction and life table parameters of Trichogramma evanescens (Hym.: Trichogrammatidae). J. Crop. Prot. 2020, 9, 89-99.

23. Calvin, D.D.; Losey, J.E.; Knapp, M.C.; Poston, F.L. Oviposition and development of Trichogramma pretiosum (Hymenoptera: Trichogrammatidae) in three age classes of southwestern corn borer eggs. Environ. Entomol. 1997, 26, 385-390. [CrossRef]

24. Jarjees, E.; Merritt, D.J.; Gordh, G. Anatomy of the mouthparts and digestive tract during feeding in larvae of the parasitoid wasp Trichogramma australicum Girault (Hymenoptera: Trichogrammatidae). Int. J. Insect Morphol. Embryol. 1998, 27, 103-110. [CrossRef]

25. Wu, Z.X.; Cohen, A.C.; Nordlund, D.A. The feeding behavior of Trichogramma brassicae: New evidence for selective ingestion of solid food. Entomol. Exp. Appl. 2000, 96, 1-8. [CrossRef]

26. Jarjees, E.A.; Merritt, D.J. The effect of parasitization by Trichogramma australicum on Helicoverpa armigera host eggs and embryos. J. Invert. Pathol. 2004, 85, 1-8. [CrossRef]

27. Romeis, J.; Shanower, T.G.; Zebitz, C.P.W. Trichogramma egg parasitism of Helicoverpa armigera on pigeonpea and sorghum in southern India. Entomol. Exp. Appl. 1999, 90, 69-81. [CrossRef]

28. El-Heneidy, A.H.; El-Awady, S.M.; El-Dawwi, H.N. Control of the tomato fruit worm, Helicoverpa armigera (Hübner) by releasing the egg parasitoid, Trichogramma evanescens West. in tomato fields in southern Egypt. Egypt. J. Biol. Pest. Control. 2010, 20, 21-26.

29. Laurentis, V.L.; Ramalho, D.G.; Santos, N.A.; Carvalho, V.F.P.; Vacari, A.M.; De Bortoli, S.A.; Veneziani, R.C.S.; Inácio, G.C.; Dami, B.G. Performance of Trichogramma pretiosum Riley (Hymenoptera: Trichogrammatidae) on eggs of Helicoverpa armigera (Hübner) (Lepidoptera: Noctuidae). Sci. Rep. 2019, 9, 1156. [CrossRef]

30. Iranipour, S.; Vaez, N.; Ghanbalani, G.N.; Zakaria, R.A.; Jafarloo, M.M. Effect of host change on demographic fitness of the parasitoid, Trichogramma brassicaE. J. Insect Sci. 2009, 10, 78. [CrossRef] [PubMed]

31. Jarjees, E.A.; Merritt, D.J. Structure of the gut contents of Trichogramma australicum Girault (Hymenoptera: Trichogrammatidae) larvae fixed in situ in eggs of its host Helicoverpa armigera (Hübner) (Lepidoptera: Noctuidae). Aust. J. Entomol. 2003, 42, 203-209. [CrossRef]

32. Pinto, J.D. Novel taxa of Trichogramma from the New World and Australia (Hymenoptera: Trichogrammatidae). J. N. Y. Entomol. Soc. 1992, 100, 621-633.

33. Shorey, H.; Hale, R. Mass rearing of the larvae of nine noctuid species on a simple artificial medium. J. Econ. Entomol. 1965, 58, 522-524. [CrossRef]

34. Godfray, H.C.J. Parasitoids; Princeton University Press: Princeton, NJ, USA, 1994.

35. Ameri, M.; Rasekh, A.; Michaud, J.P.; Allahyari, H. Morphometric indicators for quality assessment in the aphid parasitoid, Lysiphlebus fabarum (Braconidae: Aphidiinae). Eur. J. Entomol. 2013, 110, 519-525. [CrossRef]

36. SPSS. SPSS for Windows, Version 22.0; SPSS Institute Inc.: Chicago, IL, USA, 2018.

37. Birch, L.C. The intrinsic rate of natural increase of an insect population. J. Anim. Ecol. 1948, 7, 15-26. [CrossRef]

38. Maia, A.H.N.; Alfredo, J.B.; Campanhola, C. Statistical influence on associated fertility life table parameters using Jackknife technique: Computational aspects. J. Econ. Entomol. 2000, 93, 511-518. [CrossRef]

39. Godin, C.; Boivin, G. Effect of host age on parasitism and progeny allocation in Trichogrammatidae. Entomol. Exp. Appl. 2000, 97, 149-160. [CrossRef]

40. Ruberson, J.R.; Kring, T.J. Parasitism of developing eggs by Trichogramma pretiosum (Hymenoptera: Trichogrammatidae): Host age preference and suitability. Biol. Control 1993, 3, 39-46. [CrossRef]

41. Guang, L.Q.; Oloo, G.W. Host preference studies on Trichogramma sp. nr. mwanzai Schulten and Feijen (Hym: Trichogrammatidae) in Kenya. Insect Sci. Appl. 1990, 11,757-763. [CrossRef]

42. Miura, K.; Kobayashi, M. Effect of host-egg age on the parasitism of Trichogramma chilonis Ishii (Hymenoptera: Trichogrammatidae), an egg parasitoid of the diamondback moth. Appl. Entomol. Zool. 1998, 33, 219-222. [CrossRef]

43. Saour, G. Efficacy assessment of some Trichogramma species (Hymenoptera: Trichogrammatidae) in controlling the potato tuber moth Phthorimaea operculella Zeller (Lepidoptera: Gelechiidae). J. Pest. Sci. 2004, 77, 229-234. [CrossRef]

44. Stinguel, P.; Carvalho, J.R.; Pratissoli, D.; Zuim, V.; Mardgan, L. Efeito da idade dos ovos de Mocis latipes (Lepidoptera: Noctuidae) sobre o parasitismo de Trichogramma pretiosum (Hymenoptera: Trichogrammatidae) com diferentes idades. Nucleus 2013, 100, 265-274. [CrossRef]

45. Oliveira, H.N.; Santana, D.R.S.; Bellon, P.P.; Oliveira, F.C. Age influence of Diatraea saccharalis (Lepidoptera: Crambidae) on the parasitism by Trichogramma galloi (Hymenoptera: Trichogrammatidae). Interciencia 2014, 39, 46-48.

46. Tunçbilek, A.Ş.; Ayvaz, A. Influences of host age, sex ratio, population density, and photoperiod on parasitism by Trichogramma evanescens Westw. (Hym., Trichogrammatidae). J. Pest. Sci. 2003, 76, 176-180. [CrossRef]

47. Reznik, S.Y.; Umarova, T.Y.; Voinovich, N.D. The influence of previous host age on current host acceptance in Trichogramma. Entomol. Exp. Appl. 1997, 82, 153-157. [CrossRef] 
48. Takada, Y.; Kawamura, S.; Tanaka, T. Biological characteristic: Growth and development of the parasitoid Trichogramma dendrolimi (Hymenoptera: Trichogrammatidae) on cabbage armyworm Mamestra brassicae (Lepidoptera: Noctuidae). Appl. Entomol. Zool. 2000, 35, 369-379. [CrossRef]

49. Moreno, F.; Perez-Moreno, I.; Marco, V. Effects of Lobesia botrana (Lepidoptera: Tortricidae) egg age, density, and Uv treatment on parasitism and development of Trichogramma cacoeciae (Hymenoptera: Trichogrammatidae). Environ. Entomol. 2009, 38, 1513-1520. [CrossRef]

50. Paraiso, O.; Hight, S.D.; Kairo, M.T.K.; Bloem, S.; Carpenter, J.E.; Reitz, S. Laboratory biological parameters of Trichogramma fuentesi (Hymenoptera: Trichogrammatidae), an egg parasitoid of Cactoblastis cactorum (Lepidoptera: Pyralidae). Florida Entomol. 2012, 95, 1-7. [CrossRef]

51. Zhang, J.J.; Ren, B.Z.; Yuan, X.H.; Zang, L.S.; Ruan, C.C.; Sun, G.Z.; Shao, X.W. Effect of host-egg ages on host selection and suitability of four Chinese Trichogramma species, egg parasitoids of the rice striped stem borer, Chilo suppressalis. BioControl 2014, 59, 159-166. [CrossRef]

52. Waage, J.K.; Ng, S.M. The reproductive strategy of a parasitic wasp. I. Optimal progeny and sex allocation in Trichogramma evanescens. J. Anim. Ecol. 1984, 53, 401-415. [CrossRef]

53. van den Assem, J.; van Iersel, J.J.A.; Los-Den Hartog, R.L. Is being large more important for female than for male parasitic wasps? Behaviour 1989, 108, 160-195.

54. Ali, A.; Choudhury, A.R.; Ahmad, Z.; Rahman, F.; Khan, F.R.; Ahmad, S.K. Some biological characteristics of Helicoverpa armigera on chickpea. Tunisian J. Plant. Prot. 2009, 4, 99-106.

55. Zuim, V.; de Souza Rodrigues, H.; Pratissoli, D.; Freitas Bueno, C.O. Age and density of eggs of Helicoverpa armigera influence on Trichogramma pretiosum parasitism. Acta Scientiarum 2017, 39, 513-520. [CrossRef]

56. Bai, B.; Luck, R.F.; Foster, L.; Stephens, B.; Jansen, J.A.M. The effect of host size on quality attributes of the egg parasitoid, Trichogramma pretiosum. Entomol. Exp. Appl. 1992, 64, 37-48. [CrossRef]

57. Hansen, L.S.; Jensen, K.M.V. Effect of temperature on parasitism and host-feeding of Trichogramma turkestanica (Hymenoptera: Trichogrammatidae) on Ephestia kuehniella (Lepidoptera: Pyralidae). J. Econ. Entomol. 2002, 95, 50-56. [CrossRef]

58. Carey, J.R. Applied Demography for Biologists, with Special Emphasis on Insects; Oxford University Press: Oxford, UK, 1993. 